\title{
Chapter 7 \\ Disruptive Demand Side Technologies: Market Shares and Impact on Flexibility in a Decentralized World
}

\section{Stephanie Heitel, Anna-Lena Klingler, Andrea Herbst, and Francesca Fermi}

\begin{abstract}
Electricity demand is expected to increase strongly as electrification and the use of hydrogen are promising decarbonization options for the demand side sectors transport and industry. In a decentralized system with volatile renewable energy sources, flexibility potentials will play an important role for secure and costefficient electricity supply. On the demand side, decentralized PV-battery systems and electric vehicles as well as hydrogen production by electrolyzers could provide the necessary flexibility. Energy demand over time is calculated based on assumed and simulated market shares of these and other low-emission technologies. Impacts on the system and residual load are analyzed, with a focus on the contribution of load shifting as a demand-side measure. Results indicate that load shifting can contribute significantly to integrate RES electricity.
\end{abstract}

\subsection{Introduction}

Decarbonization of the transport and the industry sector will most probably result in a much higher demand for electricity (cf. Chapter 6; European Commission 2018). To cope with the volatile electricity generation of renewable energy sources (RES) and consumption peaks, more flexibility on the supply and demand side is required for a secure and cost-efficient electricity supply (cf. Chapters 9-11).

\footnotetext{
S. Heitel $(\bowtie)$

Competence Center Sustainability and Infrastructure Systems, Fraunhofer Institute for Systems and Innovation Research (ISI), Karlsruhe, Germany

e-mail: Stephanie.Heitel@isi.fraunhofer.de
}

\begin{abstract}
A.-L. Klingler
Business Area Mobility and Urban Systems Engineering, Fraunhofer Institute for Industrial Engineering (IAO), Stuttgart, Germany
\end{abstract}

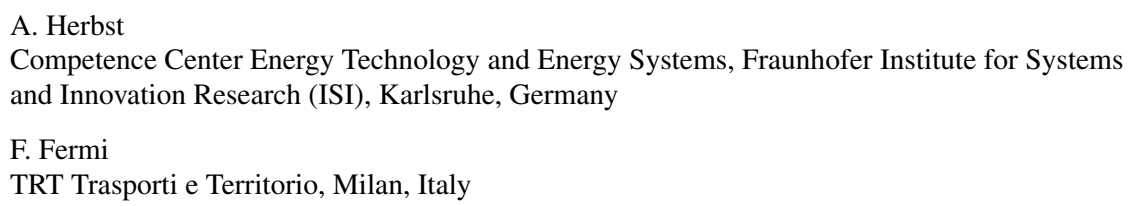


This paper focuses on analyzing flexibility potentials that can be provided by the demand side. Analyses are conducted for a decentralized energy system, meaning that hydrogen is produced locally in closer proximity to its consumers (cf. Chapter 2). In this scenario, we assume that consumers will support this decentralized system by installing rooftop PV systems and by engaging in demand side management (DSM) to provide flexibility to the system for a secure and cost-efficient electricity supply. Demand side management measures in this study aim to flatten the system load curves by reducing demand in peak times and at minimizing residual loads by adapting electricity consumption to electricity generation. The residual load is defined as the difference between system load curve and renewable electricity generation. By definition, a positive residual load means that the amount of electricity demand cannot be covered by RES. Negative residual loads occur when the production of renewable electricity exceeds the demand so that the renewable electricity cannot be integrated into the electricity system at this point in time (cf. Boßmann 2015; Chapter 6). In consequence, the reduction of negative residual loads by using demand side measures is an indicator that RES are used more efficiently. Furthermore, high fluctuations in the residual load curve can be a challenge for existing baseload power plants and could thus drive the need for additional conventional generation capacities, while the utilization, and hence profitability, of new and existing RES capacities could decline.

Compared to classical DSM measures such as heat pumps and refrigeration (cf. Chapters 8 and 12), batteries, as part of residential photovoltaic (PV) systems and in electric vehicles, as well as hydrogen electrolyzers can have a stronger role in providing flexibility in a decentralized energy system. As several decarbonization options exist for transport and industry that will have different impacts on the amount of electricity demand and the flexibility potential, the options of these sectors will be briefly described in the following.

\subsubsection{Strategies for Decarbonizing Transport}

For the decarbonization of the transport sector, several strategies are available and have to be combined to achieve the challenging greenhouse gas (GHG) reduction target: modal shift from road transport to more efficient transport modes like rail, inland waterways, public transport, and active modes, improvement of the vehicle efficiency, diffusion of low- and zero-emission technologies, and alternative fuels (cf. Chapter 6 for more details). Looking at the demand side flexibility of these options, only the vehicle technologies battery electric vehicles (BEV), plug-in hybrid vehicles (PHEV) and fuel cell electric vehicles (FCEV) can lead to demand side flexibility. $\mathrm{BEV}$ and PHEV constitute a promising technology in particular for cars and light duty vehicles. Although manufacturers are developing battery electric heavy duty trucks, hybrid trolley trucks and FCEV trucks appear to be more promising options for long-distances, as batteries for long distance trucks would be of large size and weight. It is not yet clear which of these technologies will prevail (cf. Plötz et al. 2018). Trolley trucks are more efficient from an overall energy perspective, however, 
they require a catenary system infrastructure on highways for which acceptance in the population might be an issue (cf. Wietschel et al. 2017). Concerning flexibility, trolley trucks need electricity while driving, whereas the production of hydrogen via electrolysis as fuel for FCEV offers load shifting potential.

\subsubsection{Technologies for Decarbonizing Industry}

For the decarbonization of the industry sector until 2050, a variety of different technologies and mitigation options are of importance. As available technologies and conventional fuel switch will not suffice to meet the climate targets on GHG reduction, the industry sector needs to open up remaining energy efficiency potentials in combination with high financial support for RES to promote fuel switching to biomass, power-to-heat, and power-to-gas.

In terms of end-use, most industrial GHG emissions result from high-temperature process heat, either in the form of steam or hot water or from direct firing of different types of furnaces. The high temperatures and the specific technological requirements limit the use of renewable energies to biomass or secondary energy sources. In this context, two types of electricity demand can be distinguished: the direct use of electricity for mechanical energy and heating, and the indirect use via electrolysisbased secondary energy carriers such as hydrogen (cf. Chan et al. 2019). These radical changes in industrial process technologies will be necessary to foster fuel switch to electricity and hydrogen in the iron and steel industry, the chemical industry, and the non-metallic minerals sector for electric smelting furnaces (e.g., glass industry).

To substitute coal-based primary steelmaking with steelmaking based on the direct reduction of iron ore with hydrogen, large amounts of renewable hydrogen (e.g., produced with electricity from renewable resources with Proton Electron Membrane (PEM) electrolysis) have to be available at competitive prices. Currently, a variety of different projects within the EU are working to have this technology ready for the market: the HYBRIT-project, ${ }^{1}$ the SALCOS-project ${ }^{2}$ and the $\mathrm{H}_{2}$ Future/SuSteelproject. $^{3}$

Another option to reduce emissions from primary steelmaking is the direct electrolysis of iron ore (cf. Siderwin 2018). This option also requires high amounts of renewables electricity as alkaline electrolysis is used to produce direct reduced iron from iron ore using electrical energy to replace conventional blast furnaces (cf. Chan et al. 2019).

In the basic chemical industry, the use of renewable hydrogen as feedstock can substantially reduce GHG emissions in this sector (cf. Fleiter et al. 2019; Herbst et al. 2018). Conventional ammonia and methanol production based on fossil combustion

\footnotetext{
${ }^{1}$ The implementing companies are SSAB, LKAB, and Vattenfall, cf. Vogl et al. (2018).

${ }^{2}$ The implementing companies are Salzgitter and Vattenfall, cf. https://salcos.salzgitter-ag.com/.

${ }^{3}$ The implementing companies are Voestalpine and VERBUND, cf. www.h2future-project.eu. https://www.k1-met.com/forschungsprogramm/susteel/, Chan et al. (2019).
} 
are replaced, using hydrogen-based production routes: $\mathrm{H}_{2}$ ammonia from electricity rather than through methane steam reformation and $\mathrm{H}_{2}$ methanol based on water electrolysis with electricity, followed by hydrogenation of $\mathrm{CO}_{2}$ as carbon source (cf. Chan et al. 2019; Dechema 2017).

Further emission reductions can be achieved by ethylene production via lowcarbon Methanol-to-Olefins (MTO) leading to a strong increase in methanol demand (Chan et al. 2019; Dechema 2017).

Further, radical process changes take place in the cement production, assuming the market entry of low-carbon cement sorts. In addition, a stronger switch to secondary production takes place in this scenario in the steel, aluminum, glass, and paper industry, as well as increasing efforts for material efficiency improvements and substitution.

Looking at the future flexibility potential, the largest potential in the industrial sector stems from on-site hydrogen electrolysis (if electrolyzers are installed as assumed in the scenario of this study).

\subsubsection{Focus of this Study: Disruptive Technologies with Demand Side Flexibility}

This study focuses on the three technologies that are likely to be the bulk of demand side flexibility in the long-term: decentralized batteries as part of residential PV systems and in electric vehicles, as well as electrolyzers for the production of $\mathrm{H}_{2}$ as fuel for freight transport and as feedstock and fuel for the industry sector. The target is to analyze their potential impact via load shifting on the residual load as an indicator for RES integration.

In the next Sect. 7.2, these three technologies will be described in more detail including their current status and factors influencing their diffusion. Section 7.3 describes the detailed scenario assumptions for a decentralized world (based on the decentralized High-RES scenario cf. Chapter 2), the model coupling approach and the methods used to calculate and simulate the diffusion of the respective technologies. In Sect. 7.4, the results are presented comprising the installed battery capacities as part of PV systems, technology diffusion in the vehicle fleet, radical process improvements in industry and the resulting demand for electricity and hydrogen. Section 7.5 analyses the impacts of these technologies on demand side flexibility. Finally, the results are discussed and conclusions including policy recommendations are drawn. 


\subsection{Disruptive Technologies with Flexibility Potential}

\subsubsection{Photovoltaic Systems and Stationary Batteries}

In terms of the economic performance of residential PV systems, the rate of on-site consumed electricity (so-called self-consumption) is becoming ever more important due to increasing electricity prices and decreasing feed-in remuneration. Selfconsumption is particularly profitable in markets with high electricity end-user prices and relatively low levelized costs of electricity for PV. Relatively low or no feed-in remuneration promote high self-consumption rates. In order to increase self-consumption, battery systems are available, which allow matching the electricity production of PV systems and the household's consumption (cf. Schill et al. 2017). Due to increasing production capacities and technological learning, prices for batteries are expected to decrease substantially (cf. Louwen et al. 2018; Schmidt et al. 2017; cf. Chapter 4). Lithium-ion batteries are currently the dominant technology (cf. Figgener et al. 2017).

Batteries for the enhancement of self-consumption are therefore widely discussed and are already selling in some local markets. In Germany, with its high end-consumer electricity prices, about every second rooftop PV system is already combined with a battery: In 2016, 45\% of new PV installations under $30 \mathrm{~kW}$ in Germany included a battery (cf. Figgener et al. 2017). Moreover, Barbour and González (2018) find that 'PV + battery systems' are to become a better investment than 'PV only systems'. The expectation of a broad diffusion of stationary batteries sparks the hope that this technology will provide necessary flexibility for the future electricity system. Recent studies find that participating in the balancing power markets could potentially increase economic benefits for the battery owner (cf. Stahl et al. 2018; Sterner et al. 2015). Due to complicated legislation, this option is still at its very early stages but is seen as viable to fill the need for more flexibility in the system.

\subsubsection{Battery Electric Vehicles}

Global electric car sales and market shares are rapidly growing (cf. Chapter 5). In 2018, the new registrations nearly doubled the registrations of the previous year. The global electric car fleet achieved over 5.1 million vehicles (cf. International Energy Agency 2019). These numbers comprise BEV, in which batteries are the only energy source, and PHEV, which still incorporate an internal combustion engine (ICE) and contain smaller batteries. Looking at the market shares of new electric cars, Norway is the global leader with $46 \%$, followed by Iceland with $17 \%$ and Sweden with $8 \%$ (cf. International Energy Agency 2019). These numbers show that electric vehicles (EVs) are a real technological option to decarbonize road transport and reduce air pollutants. Declining battery prices due to global learning effects in production (cf. Chapter 5; Heitel et al. 2019; Schmidt et al. 2017) are an important driver for the 
diffusion. EVs may soon achieve cost-parity with conventional vehicles based on the total cost of ownership (TCO). Further drivers will be technological improvements, like raising durability and energy density that enables longer ranges, as well as policies that incentivize automobile manufacturers to build up an EV portfolio. A high EV uptake will increase electricity demand and can challenge the power system in case of uncoordinated charging in times of peak demand, causing local overloading of distribution networks and the need for additional electricity generation. In contrast, however, EVs can also contribute to flexibility with DSM. The provided flexibility potential depends on several factors, in particular, the available charging infrastructure and charging patterns (cf. Gnann et al. 2018), and the willingness to participate in load shifting so that the timing of charging can be postponed to low-demand periods.

Such a controlled charging mechanism provides a respective flexibility potential that could even be enhanced through bidirectional charging, which would transform EVs into a distributed electricity storage from which electricity can be fed back to the grid or home (cf. International Energy Agency 2019). Besides regulation, willingness to allow load shifting will depend on price incentives that should compensate for disadvantages like reduced spontaneity for taking the car or a faster degradation of the battery due to more frequent and rapid charging cycles.

\subsubsection{Hydrogen Electrolysis}

The electrolysis of water into hydrogen and oxygen has the potential to become a key element in coupling the electricity, transport and industry sectors by providing fossilfree fuels and feedstock in a future sustainable world. Additionally, electrolyzers can provide flexibility to the electricity system: According to Buttler and Spliethoff (2018), the technological development of the last few years shows that electrolysis is on its way to large-scale flexible energy-storage applications.

Large-scale electrolysis systems, which are in the focus of this study, consist of several electrolyzers in parallel. Therefore, it is possible to vary the power consumption of the overall system over a wide range by switching off individual electrolyzers. In this manner, current state of the art systems allow for a load flexibility of 0-100\% of the nominal load (this applies for PEM electrolysis, cf. Buttler and Spliethoff 2018). Additionally, 20\% overcharging is possible without significant effects on the lifetime (alkaline electrolysis, cf. Gutiérrez-Martín et al. 2015).

Since the large-scale operation of electrolyzers for the decarbonization of the energy system is still an emerging market, the mode of operation, whether decentralized (local electrolyzers) or centralized (with infrastructure carrying $\mathrm{H}_{2}$ ) is uncertain and both can be assumed (cf. De Vita et al. 2018). On the demand side, the future requirement of $\mathrm{H}_{2}$ in the transport and industry sector is expected to drive the market uptake of this technology. 


\subsection{Scenario Assumptions and Methodology}

\subsubsection{Scenario Assumptions for High-RES Decentralized}

For the High-RES decentralized scenario, several strong measures are assumed to accelerate the decarbonization in order to achieve the GHG reduction targets and specific characteristics of a decentralized energy system are considered.

To support decentralized PV electricity generation, it is assumed that all European countries allow feeding PV electricity into the public grid. The electricity can be sold to the current market prices, while feed-in tariffs and premiums are abolished. Self-consumed PV electricity is not burdened with any surcharges, taxes, or levies.

Policies and assumptions that accelerate the diffusion of BEV and PHEV comprise a strong expansion of charging stations, increased taxes for conventional fuels and for the registration of ICE vehicles, and a sales ban for new ICE cars as of 2040. In this scenario, fuel cells are pushed as the future technology for trucks by R\&D expenditures, deployment of a hydrogen filling station infrastructure for trucks, and a decision against the installation of catenary systems for hybrid trolley trucks. In the decentralized world, hydrogen is produced on-site at the filling stations. As households with rooftop PV have a higher probability to buy an electric car (as indicated by some studies, cf., e.g., Scherrer et al. 2019) due to financial advantages by consumption of self-produced electricity and higher technical familiarity, the EV sales are further supported by strongly increasing PV installations. Besides, it is assumed that multi-modal transport is more accepted in a decentralized world which leads to increasing demand for car sharing vehicles that are predestinated for higher electric shares in their fleet (cf. International Energy Agency 2019).

Due to radical process improvements, a strong shift toward electricity and hydrogen takes place in the iron and steel industry (DR electrolysis, $\mathrm{H}_{2}$ plasma, DR $\mathrm{H}_{2}+\mathrm{EAF}$ ) and the glass industry (electric melting). Furthermore, the production of ammonia, methanol and consequently ethylene is no longer based on fossil sources (e.g., natural gas, naphtha) leading to a significant drop in demand for refinery products but increasing the need for RES hydrogen. Hydrogen is produced on-site for industrial purposes and consequently leading to a high on-site industrial electricity demand for hydrogen electrolysis.

Table 7.1 summarizes the main assumptions for the High-RES decentralized scenario that are characteristic for a decentralized energy system.

Furthermore, we assume that DSM measures will be stipulated in the near future to facilitate renewable integration on a local level. Therefore, ambitious shares of flexible technologies (referred to as "smart share") are assumed. New flexibility options, namely, decentralized batteries and hydrogen electrolyzers, are considered to be $100 \%$ DSM ready from the time of their installation. "Classic" flexible technologies, such as heat pumps, refrigeration, etc., gain the DSM option with their refurbishment. As hydrogen is produced on-site at the industrial plants and at the filling stations for transport, the electricity consumption and flexibility potential is 
Table 7.1 Main scenario assumptions for the High-RES decentralized scenario

\begin{tabular}{l|l}
\hline PV \& stationary batteries & Main assumptions for a decentralized energy system \\
\hline Transport & $\begin{array}{l}\text { Feed-in of PV electricity to the public grid is allowed in all } \\
\text { European countries. The electricity can be sold to the current market } \\
\text { prices. Feed-in tariffs and premiums are abolished } \\
\text { There are no surcharges, taxes, or levies on self-consumed PV } \\
\text { electricity }\end{array}$ \\
& $\begin{array}{l}\text { Strongly increasing number of households with rooftop PV } \\
\text { accelerates the diffusion of electric vehicles } \\
\text { Hydrogen for FCEV trucks is produced on-site at the filling stations } \\
\text { Higher acceptance of multi-modal transport increases the use of car } \\
\text { sharing vehicles that have a higher share of electric drives }\end{array}$ \\
\hline Industry & $\begin{array}{l}\text { Faster diffusion of incremental process improvements (Best } \\
\text { Available Technologies and Innovations } \geq \text { TRL 5) } \\
\text { High financial support for RES technologies (biomass, } \\
\text { power-to-heat, power-to-gas) } \\
\text { Radical changes in industrial process technologies drive fuel switch } \\
\text { to electricity and hydrogen (Innovations } \geq \text { TRL 5). Hydrogen for } \\
\text { industry is produced decentrally on industrial sites } \\
\text { Stronger switch to secondary production (e.g., EAF steel) and } \\
\text { increasing material efficiency and substitution }\end{array}$ \\
\hline
\end{tabular}

Table 7.2 Assumed participation in DSM (i.e., "Smart share") over time in percentage, based on the assumption of a stipulated participation

\begin{tabular}{l|l|l|l|l}
\hline & $2020(\%)$ & $2030(\%)$ & $2040(\%)$ & $2050(\%)$ \\
\hline Tertiary, industry sector & 6 & 50 & 92 & 99 \\
\hline Residential sector & 3 & 50 & 92 & 99 \\
\hline Hydrogen electrolysis & 100 & 100 & 100 & 100 \\
\hline Stationary batteries & 100 & 100 & 100 & 100 \\
\hline Electric vehicles & 8 & 50 & 92 & 99
\end{tabular}

accounted for on the demand side. The smart shares for the tertiary, industry, and residential sectors as well as for batteries and electrolyzers are presented in Table 7.2.

\subsubsection{Model Coupling Approach}

For the simulation of the High-RES decentralized scenario across sectors, several models were coupled by data exchange in two iterations to include feedback mechanisms like the changing electricity price with the diffusion of additional demand side technologies (cf. Chapter 3 for more details on the single models and the data exchange). In the following, only the main models, linkages, and outputs that are required for the analysis of flexibility provided by the demand side are briefly 
explained. The two models-FORECAST, covering the industry, tertiary and residential sectors, and ASTRA, representing the transport sector-simulate the development of the annual electricity and hydrogen demand until 2050 by technology and consumer type, such as specific industrial processes or vehicle categories. In eLOAD, this annual demand is then translated to hourly demand curves by using load profiles of various technologies and consumer types. The resulting hourly system load curves are then optimized using demand side management with the assumed smart shares, to flatten the system load, and to reduce the negative residual load. For the calculation of the residual load, intermittent RES electricity from wind and PV are calculated by geographically highly resolved data on land availability as well as hourly time series of RES generation based on weather data, as described in Zöphel et al. (2019) and Slednev et al. (2018). Methods addressing the diffusion of the relevant technologies are described in the following section.

\subsubsection{Methods Used for Technology Diffusion}

\subsubsection{Calculation of PV and Battery System Diffusion}

The market diffusion of decentralized battery systems in households is calculated in five steps: first, the optimal (self-consumption maximizing) battery operation is calculated. In a subsequent step, the economic benefits of the battery system are assessed for batteries with different capacities, and the — on average — optimal battery capacity is selected with the assumption that feed-in premiums and tariffs are abolished, and the electricity produced by PV systems can be sold to the public grid at spot market rates. In the third step, Rogers' theory on the diffusion of innovation (cf. Rogers 2003) is applied to assess the share of battery adopters among PV system owners. Based on the share of adopters and the current and future population of PV system owners, the total population of battery adopters is calculated in a fourth step. In a final step, the installed battery capacity is given for the years 2016 to 2050. The calculations and assumptions are described in more detail in Klingler et al. (2019).

\subsubsection{Diffusion of Alternative Drive Technologies for Vehicles}

In ASTRA, the technology choice is implemented based on an adapted TCO approach that considers the following factors: vehicle prices, costs for energy consumption, maintenance costs, taxes, insurance, road charges as well as fuel procurement costs which depend on the deployment of the charging and filling station infrastructure and the ranges of the vehicles. The costs of the two new technology components i) battery and ii) fuel cell stack as part of the vehicle prices develop via experience curves covering global learning. Further qualitative aspects of purchase decisions related to a certain technology (like the anxiety of gas explosions or insufficient ranges, limited available vehicle models, etc.) are covered in a "residual disutility" 
term. The diffusion of technologies in the road vehicle fleet is simulated separately for the vehicle categories private cars, commercial cars, light duty vehicles, heavy duty vehicles in four separate gross vehicle weight categories, urban buses, and coaches. A set of suitable technologies is available for each category. The technology share for new vehicle purchases in each category is finally estimated with a discrete choice approach per country. The methodology is described in more detail in Heitel et al. (2019) and Krail (2009).

\subsubsection{Assumptions for Technology Shares in Industry}

The diffusion of new production processes is an exogenous assumption in FORECAST. Data on potential market entry and maximum diffusion rates were determined in previous projects by means of expert surveys and interviews (cf. Eichhammer et al. 2018) as well as literature analysis (cf. Chan et al. 2019). Therefore, the scenario can say little about the actual speed of process replacement and diffusion. It can, however, allow important conclusions on the overall direction of process change.

For the iron and steel industry, it has been assumed that oxygen steel will be replaced as far as possible with electric steel and that the remaining blast furnace route will be substituted with electrolysis-based direct reduction and hydrogen-based steel production routes $\left(\mathrm{H}_{2}\right.$ plasma steel, $\left.\mathrm{DR} \mathrm{H}_{2}+\mathrm{EAF}\right)$.

In the chemical industry, it is assumed that the production of ammonia, methanol, and consequently ethylene is no longer based on fossil sources (e.g., natural gas, naphtha) but fully substituted by renewable hydrogen and ammonia production as well as methanol-to-ethylene production in 2050 .

\subsection{Results: Diffusion of Technologies and Energy Demand}

\subsubsection{Installed Battery Capacity}

In the mid- to long-term future, larger batteries are installed in residential PV selfconsumption systems, due to decreasing technology costs. Based on technological learning, the specific investment decreases substantially, from 1,250 EUR/kWh in 2017 to 346 EUR/kWh in 2050 (cf. Klingler et al. 2019). Apart from the country of Norway, where the low electricity prices inhibit the batteries to gain an economic case, this cost development allows for high diffusion and large systems. In 2050, over 80 million batteries are expected in the EU-27 $+\mathrm{CH}+\mathrm{NO}+\mathrm{UK}$, i.e., over $90 \%$ of the households with a PV rooftop system own a battery.

Table 7.3 shows the resulting on average installed battery capacity and Table 7.4 the total installed battery capacity for selected EU countries and the entire EU covering EU-27 + $\mathrm{CH}+\mathrm{NO}+\mathrm{UK}$. 
Table 7.3 Most economic battery capacity in kWh for the average household in selected countries in the years 2020, 2030, 2040, and 2050

\begin{tabular}{l|l|l|l|l|l|l|l|l|l}
\hline Country & 2015 & 2016 & 2017 & 2018 & 2019 & 2020 & 2030 & 2040 & 2050 \\
\hline DE & 0 & 0 & 2.5 & 5 & 5 & 5 & 5 & 5 & 5 \\
\hline ES & 0 & 0 & 5 & 5 & 5 & 7.5 & 7.5 & 7.5 & 7.5 \\
\hline FR & 0 & 0 & 2.5 & 5 & 5 & 7.5 & 7.5 & 7.5 & 7.5 \\
\hline IT & 0 & 0 & 2.5 & 2.5 & 5 & 5 & 5 & 5 & 5 \\
\hline NL & 0 & 0 & 0 & 2.5 & 2.5 & 2.5 & 5 & 5 & 5 \\
\hline PL & 0 & 0 & 0 & 0 & 2.5 & 2.5 & 2.5 & 2.5 & 5 \\
\hline UK & 0 & 0 & 0 & 2.5 & 5 & 5 & 7.5 & 7.5 & 7.5 \\
\hline
\end{tabular}

Source Data based on own calculations

Table 7.4 Expected installed battery capacity in MWh in Europe and in selected EU countries

\begin{tabular}{l|l|l|l|l}
\hline Country & 2020 & 2030 & 2040 & 2050 \\
\hline DE & 2,404 & 39,003 & 54,865 & 63,861 \\
\hline ES & 162 & 14,186 & 45,873 & 68,563 \\
\hline FR & 1,264 & 36,108 & 73,182 & 100,286 \\
\hline IT & 250 & 13,067 & 28,725 & 62,404 \\
\hline NL & 0 & 2,000 & 6,392 & 5,329 \\
\hline UL & 0 & 829 & 7,671 & 10,236 \\
\hline EU-27+ CH + NO + UK & 0 & 6,053 & 36,033 & 45,942 \\
\hline
\end{tabular}

Source Data based on own calculations

\subsubsection{Vehicle Fleet Technology Composition and Resulting Energy Demand}

With the assumptions for the High-RES decentralized scenario, BEV, PHEV, and FCEV diffuse substantially in the car fleet, comprising over $80 \%$ of total passenger car stock of the EU-27 countries and the UK in 2050. Decreasing battery prices, stricter $\mathrm{CO}_{2}$ standards for cars, extended charging infrastructure, diverse financial measures, and an increasing number of households with rooftop PV systems lead to a visible diffusion of BEV and PHEV in the upcoming decades. The diffusion accelerates from the year 2035 onwards as sales of new conventional ICE cars (i.e., gasoline, diesel, liquefied petroleum gas [LPG], and compressed natural gas [CNG]) are banned from 2040 onwards, having effects on car manufacturer's vehicle portfolios and purchase decisions already in the previous years.

For road freight transport, diesel remains the dominant fuel for the next two decades. BEV and PHEV prevail for trucks of the lightest weight category as prices for batteries decline, the number of available vehicle models increases and a growing 
number of cities restricts the entry of ICE vehicles. With more ambitious policies that increase costs for diesel trucks (i.e., stricter $\mathrm{CO}_{2}$ standards, emission-based registration taxes, fuel taxes, and road tolls) and a reliable $\mathrm{H}_{2}$-refueling infrastructure for heavy-duty vehicles, FCEV diffuse in the truck fleet as of 2030, achieving a share of $36 \%$ of all trucks in 2050. In order to enable market-entry based on a TCO approach, R\&D and subsidies for fuel cell technology and hydrogen supply are required initially. Over time, the related cost further decline via experience curve effects for the production of fuel cell stacks and electrolyzers.

Figure 7.1 visualizes the diffusion of the low- and zero-emission technologies in the main road vehicle fleets in the High-RES decentralized scenario.

The resulting demand for electricity and hydrogen is depicted in Fig. 7.2. While the final electricity demand for the transport sector stems mainly from trains in 2015 ,

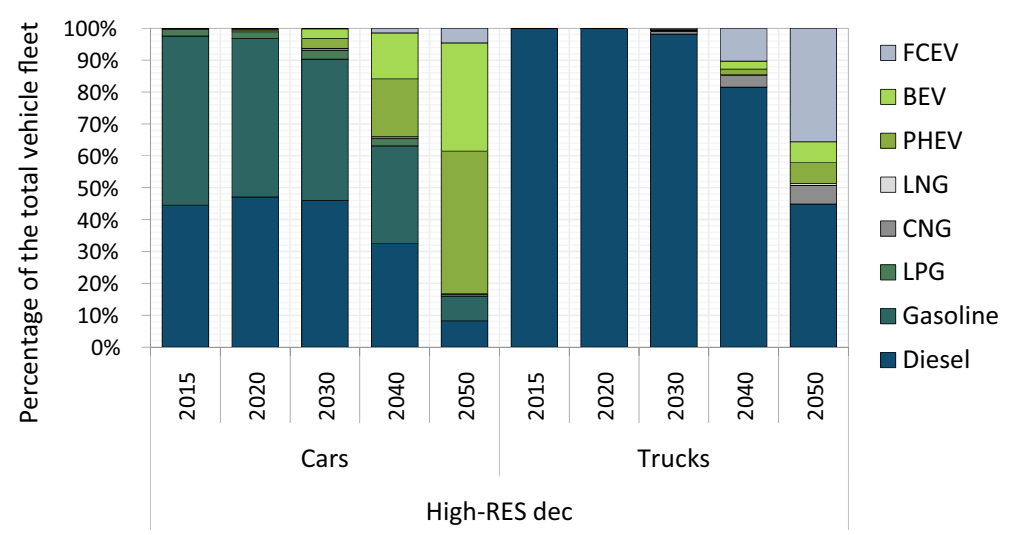

Fig. 7.1 Technology composition of the vehicle fleet in the High-RES decentralized scenario for cars and trucks for EU-27 + UK (Source Data based on model results from ASTRA)

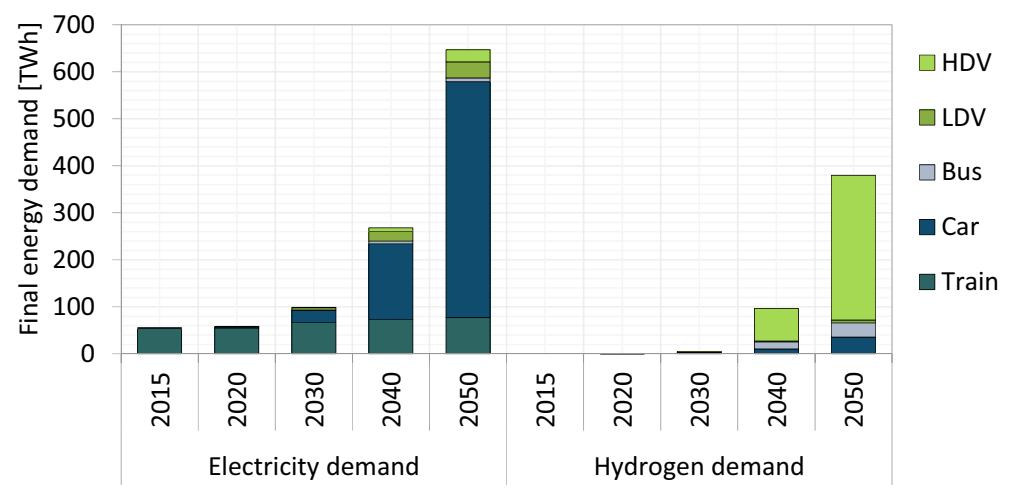

Fig. 7.2 Final electricity and hydrogen demand of the transport sector in High-RES decentralized for EU-27 + UK in TWh (Source Data based on model results from ASTRA) 
the sector's electricity demand increases by ten times to $547 \mathrm{TWh}$ in 2050 due to the diffusion of BEV and PHEV. Therein, electric passenger cars are the dominant consumers. They represent $88 \%$ of electricity demand from road transport and $14 \%$ with regard to total electricity demand.

The final hydrogen demand of the transport sector is strongly increasing from 2030 onwards with the diffusion of fuel cell trucks, reaching 380 TWh by 2050 . Although hydrogen is also demanded by cars, light duty vehicles (LDV), and buses, $80 \%$ of the hydrogen required for the transport sector will be consumed by heavy duty vehicles (HDV).

\subsubsection{Radical Process Improvements in Industry and Their Implications for Future Electricity Demand}

In the High-RES decentralized scenario, a significant reduction of direct emissions in the industry sector is achieved (73\% compared to 2015). This high level of ambition leads to a significant increase in demand for RES electricity and RES hydrogen in 2050, making electricity the dominant energy carrier in 2050 (from 1,036 TWh to 1,469 TWh in 2050, cf. Figure 7.3). Process technologies in 2050 use electricity either directly (e.g., DR electrolysis in the steel industry) or indirectly (e.g., production of ethylene via $\mathrm{H}_{2}$-based methanol). Where possible, the direct use of electricity is preferred over the indirect use (e.g., electric kilns and furnaces). In general, electricity, ambient heat, and biomass substitute a large part of industry's demand for natural gas in this scenario.

In 2050, 42 TWh hydrogen use is assumed in the High-RES decentralized scenario within the iron and steel industry for direct reduction. $\mathrm{H}_{2}$ feedstock use is assumed to take place at a large-scale leading to additional $384 \mathrm{TWh}$ of hydrogen demand to the industrial final demand (cf. Figure 7.3 and Fig. 7.4). When produced onsite, this hydrogen demand together with the strong electrification of the industry sector lead to a doubling of industrial electricity demand in 2050 compared to 2015 (from 1,036 TWh to 2,078 TWh in 2050). Only the hydrogen demand for feedstock translates into approximately $549 \mathrm{TWh}$ of additional electricity demand (cf. Figure 7.4).

\subsection{Impacts of Disruptive Technologies on Demand Side Flexibility}

With the ambitious electrification in the demand side sector, the electricity consumption in the High-RES decentralized scenario is much higher in 2050 compared to today's level. The high electricity demand in the study stems in particular from the assumption that hydrogen, for the transport sector as well as for feedstock and fuel in 


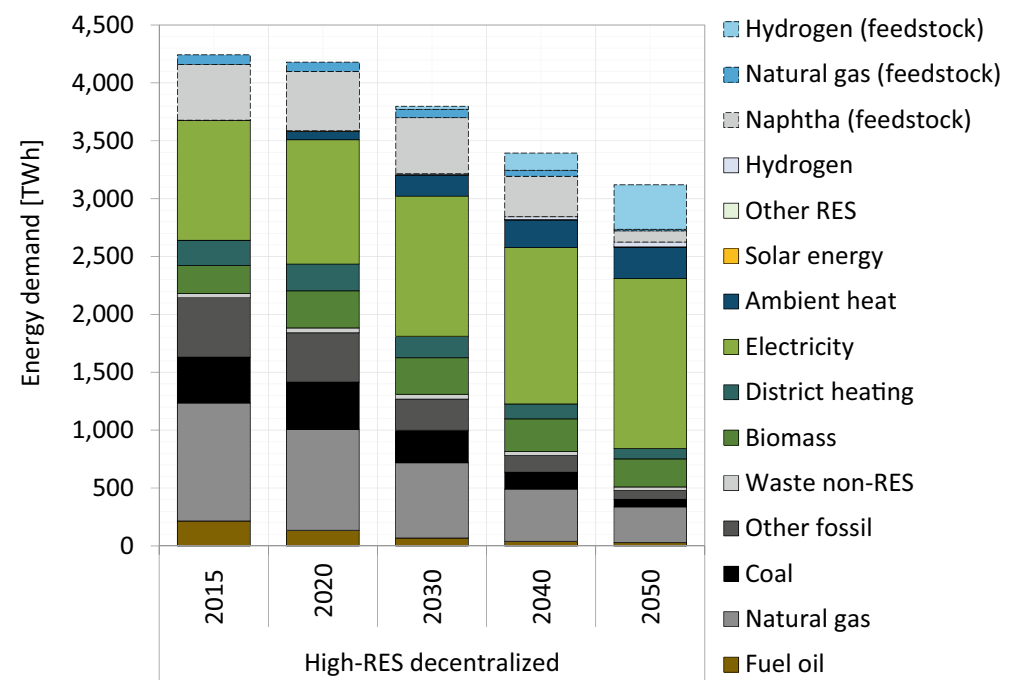

Fig. 7.3 Industrial final energy demand by energy carrier including feedstock demand for EU-27 + UK (2015-2050) (Dotted bars relate to feedstock demand. Hydrogen is split up into feedstock and energetic use. Electricity consumption does not include demand for hydrogen electrolysis. Source Data based on model results from FORECAST)

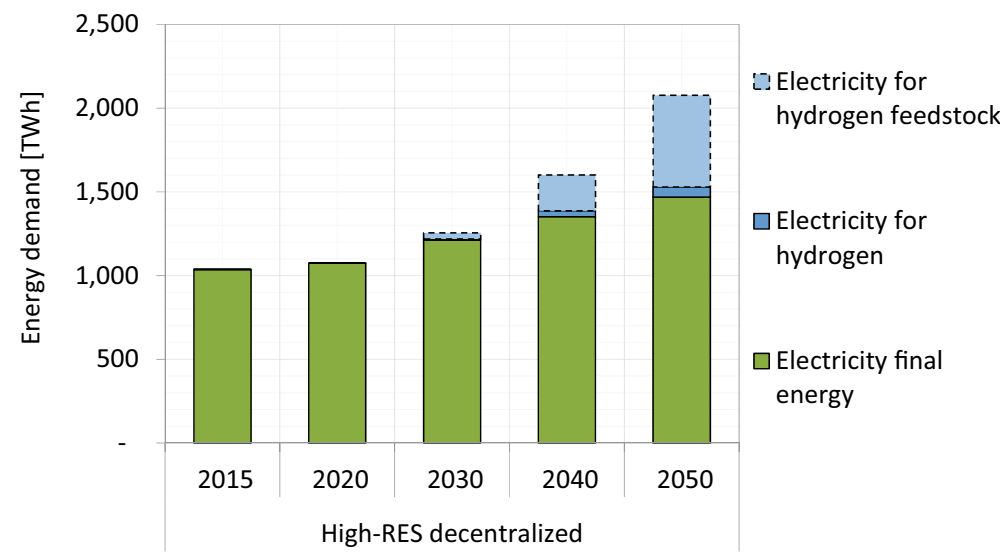

Fig. 7.4 Industrial final electricity demand including demand for hydrogen electrolysis for EU-27 + UK (2015-2050) (Source Data based on model results from FORECAST)

the industry sector, is produced via electrolysis decentralized at the filling stations and in industrial plants. Thus, the electricity consumption for electrolyzers is included in the system load and thus increases the national and EU-wide electricity demand. The electrolyzers feature a band-like profile with high full load hours, therefore the 
electricity demand increases in all hours of the year if no demand side management is applied.

Besides the hydrogen production, the future system load is expected to increase due to electricity consumption by battery electric vehicles. The charging of electric vehicles occurs in the High-RES scenario after the last trip at home, and additionally at the workplace. This particular charging pattern leads to load peaks in electricity consumption on midday and in the evening. Since electric vehicle charging makes up a substantial amount of the overall electricity consumption, the charging pattern shows in the system load curve (Fig. 7.5, left part).

Besides the analysis of structural changes in the system load curve, the changes in the residual load curve (i.e., the system load curve minus the renewable electricity production) are important to address. Figure 7.5 (right part) depicts the average residual load in summer and winter for the countries EU-27 $+\mathrm{CH}+\mathrm{NO}+\mathrm{UK}$ for the years 2020 and 2050. The increasing electricity consumption in the scenarios together with a higher amount of RES generation results in highly fluctuating residual loads and an increasing amount of negative residual load. A negative residual load indicates that an excess of renewable electricity is produced, i.e., the renewable electricity cannot be consumed within the system. The fluctuating or even negative residual load usually corresponds with equally highly fluctuating electricity prices, leaving room for DSM to exploit the arbitrage.

Figure 7.6 shows the shifted load due to DSM as the sum of load shifting in the countries EU-27 + CH + NO + UK in the High-RES decentralized scenario. Since we assumed high participation rates in this scenario, the results give an indication of the potential of DSM measures to smoothen the residual load and absorb price fluctuations. For better readability, the DSM processes in the figure are grouped: Ventilation and air-conditioning (V\&AC) contains loads of the household and tertiary sector, the

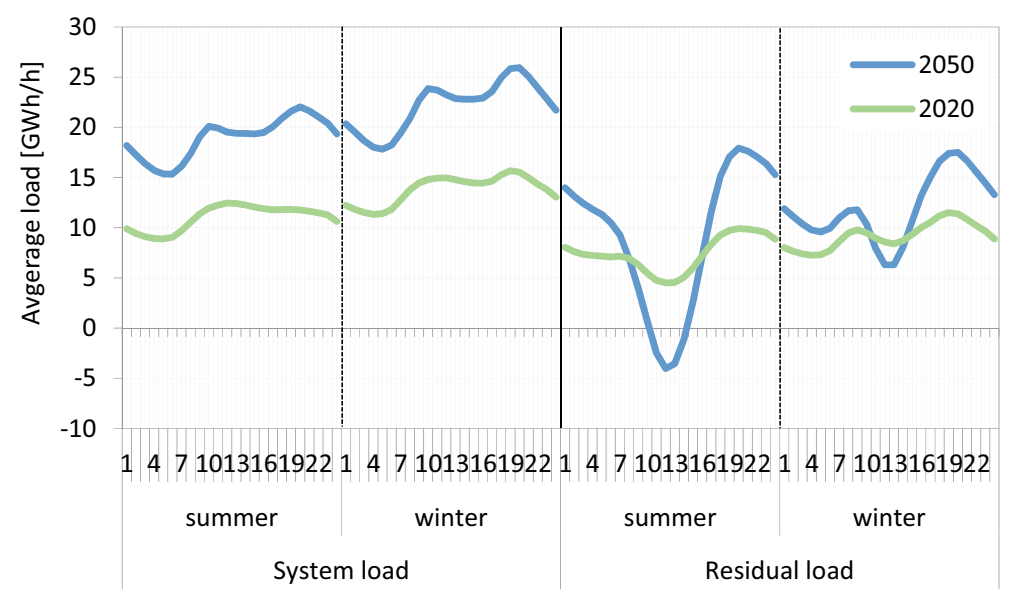

Fig. 7.5 Average system (left) and residual load (right) in summer and winter for EU-27 $+\mathrm{CH}+$ $\mathrm{NO}+\mathrm{UK}$ in 2020 and 2050 (Source Data based on model results from eLOAD) 


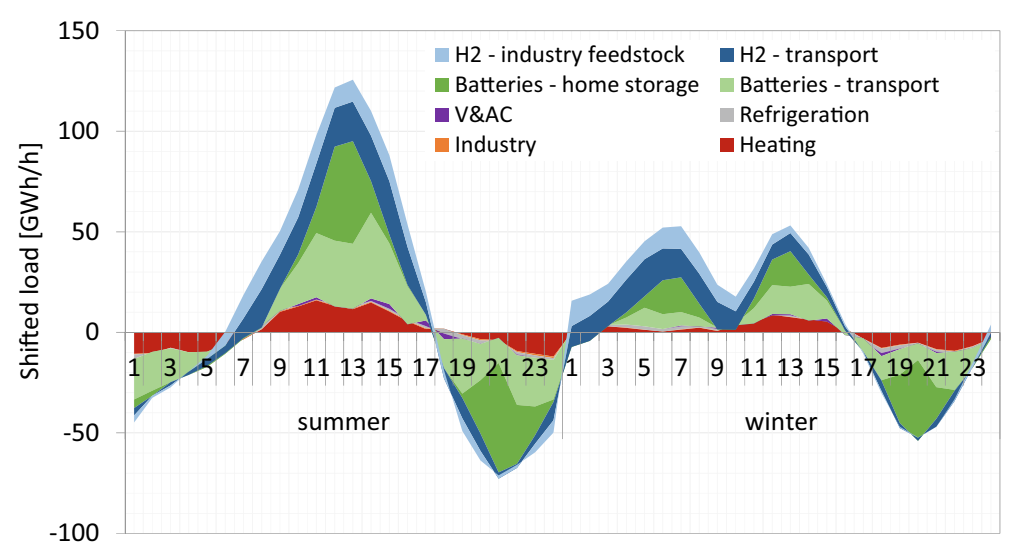

Fig. 7.6 Average shifted load in summer (left) and winter (right) for EU-27 + CH + NO + UK in 2050, distinguished by DSM process (Source Data based on model results from eLOAD)

same for electrical heating that is mainly heat pumps, but also contains direct electric heating and storage heating. "Industry" groups all industrial DSM processes, i.e., electric arc furnace, cement grinding, mechanical pulp. Equally, private and commercial battery electric vehicles are grouped (Batteries-transport).

Figure 7.6 shows that, in 2050 in the summer season, load is shifted mostly from night hours toward the middle of the day with high PV production and low or negative residual loads. In the winter season, the flexible loads are additionally shifted to the early morning hours with low electricity demand and therefore a relatively low residual load.

The resulting system and residual load curves of the load shifting is depicted for average summer and winter days in the years 2020 and 2050 in Fig. 7.7. The system load curve in the right part that represents the average electricity consumption of the $\mathrm{EU}-27+\mathrm{CH}+\mathrm{NO}+\mathrm{UK}$ shows that the electricity consumption increases in the midday hours due to the flexible deployment of decentralized hydrogen production, batteries and other, smaller flexible technologies. The residual load curves in the right part show a reduction of the hours with negative loads, i.e., on average, there is no excess electricity produced. Due to the high amount of flexibility in the future electricity consumption (e.g., in hydrogen production), the residual load shows an almost flat profile. For example in Germany, the residual load's standard deviation is reduced by $75 \%$ in 2050 compared to the residual load without load shifting.

Looking at the average summer and winter days depicted in Fig. 7.7, which reflects the sum of all EU-27 + CH + NO + UK countries, the issue of excess RES electricity production seems to be largely absorbed by higher and more flexible electricity consumption in the future. However, by the view on a country level, we find that for some countries there is still excess RES electricity produced. In particular in countries with high renewable potentials and relatively small (flexible) electricity consumption. Figure 7.8 illustrates the maximum available flexible load in the EU- 


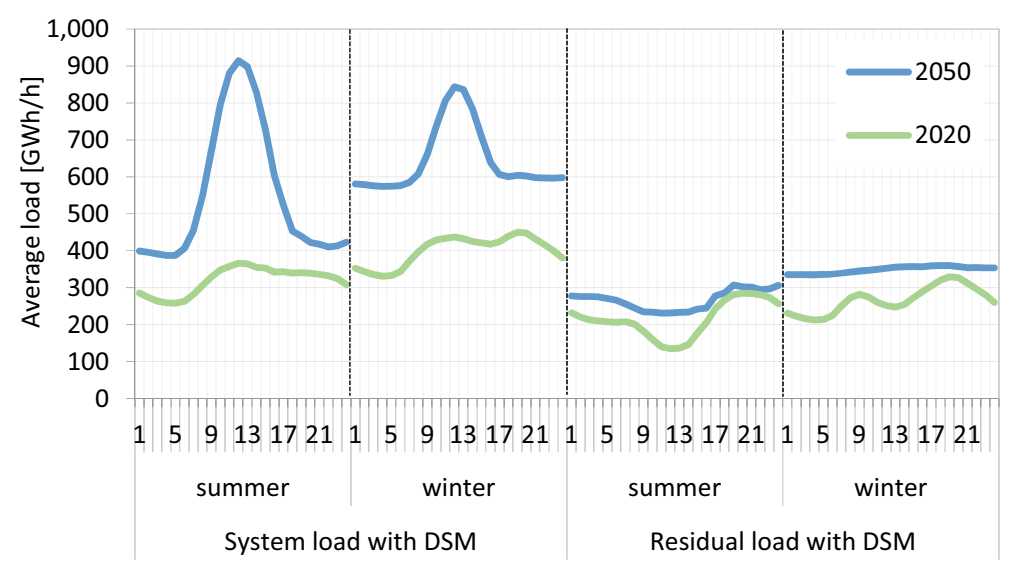

Fig. 7.7 Average system (left) and residual load (right) after DSM optimization in summer and winter for EU-27 + CH + NO + UK in 2020 and 2050 (Source Data based on model results from eLOAD)

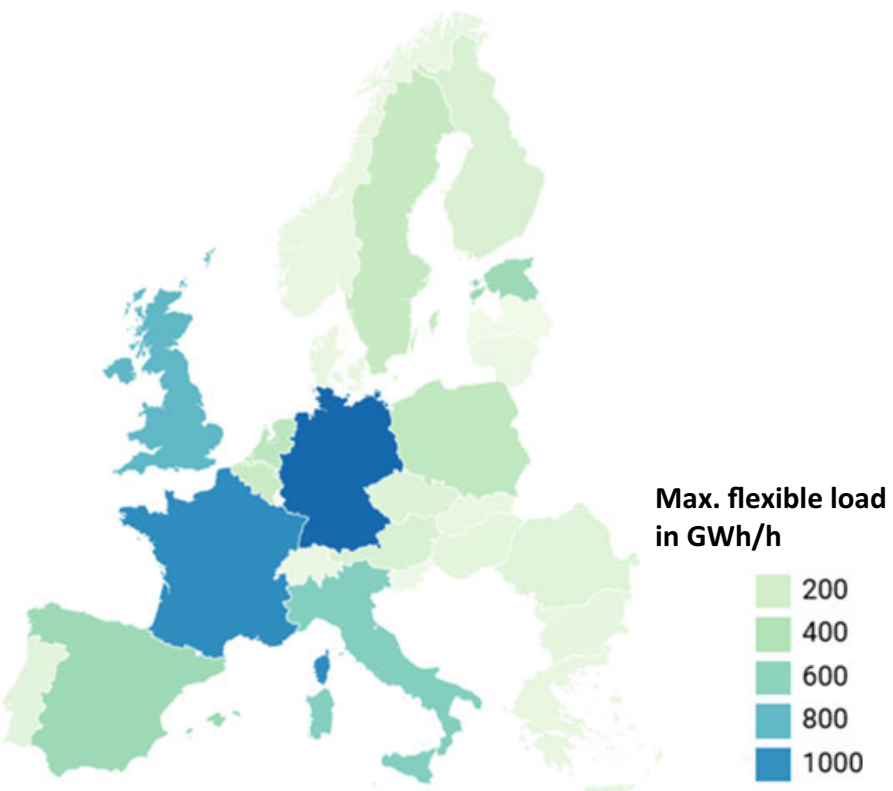

Fig. 7.8 Maximum shiftable load in the countries of the EU-27 + CH + NO + UK in 2050 (Source Data based on model results from eLOAD) 
Table 7.5 Negative residual load vs. integrated RES for the largest EU countries and the entire EU-27 + CH + NO + UK in the High-RES decentralized scenario in TWh

\begin{tabular}{l|l|l|l|l|l|l|l|l}
\hline & FR & DE & ES & IT & NL & PL & UK & $\sum$ EU-27 + CH/NO/UK \\
\hline $\begin{array}{l}\text { Neg. residual load } \\
\text { without DSM }\end{array}$ & 0.3 & 1.6 & 0.0 & 0.0 & 22.2 & - & 26.7 & $\mathbf{5 5}$ \\
\hline $\begin{array}{l}\text { Reduction of negative } \\
\text { residual load via DSM }\end{array}$ & 0.3 & 1.5 & 0.0 & 0.0 & 9.5 & - & 14.8 & $\mathbf{2 7}$ \\
\hline
\end{tabular}

$27+\mathrm{CH}+\mathrm{NO}+\mathrm{UK}$ in the year 2050. The large European economies, e.g., Germany, France, and the UK, show the highest potential for flexible adjustments of their electricity demand. However, due to their high future electricity demand and limited RES production, they are not necessarily the countries with large excess electricity production.

Table 7.5 lists the amount of negative residual load in the largest European countries and the entire EU-27 $+\mathrm{CH}+\mathrm{NO}+\mathrm{UK}$, and the reduction of negative residual load by means of load shifting as the most relevant DSM measure. The reduction of negative residual load is an indicator of RES electricity that was integrated into the electricity system due to DSM.

The Table 7.5 shows that countries, such as the UK and the Netherlands, with high flexible electricity demand and a high RES electricity feed-in, are able to apply their flexibility potential to integrate excess renewable electricity. Other countries, such as France and Spain, cannot fully use their flexibility potential for the integration of RES due to the limited renewable electricity generation.

\subsection{Discussion and Conclusions}

Market shares of the disruptive demand side technologies as shown in this chapter, especially focusing on the decentralized High-RES scenario, would enable to decarbonize the industry and the transport sector to an extent that their GHG reduction sector targets are achieved. However, to obtain this level of diffusion of innovative technologies and processes, strong measures and policies are required within the next decades to support market penetration.

For the diffusion of low- and zero-emission vehicles, financial incentives relative to conventional vehicles are required, implemented, e.g., by fuel taxes, registration fees, $\mathrm{CO}_{2}$ prices, road charges, subsidies, or $\mathrm{R} \& \mathrm{D}$ expenditures. In addition, the infrastructure for charging, including fast chargers, and for fuels like hydrogen must be deployed in a reliable extent across countries to avoid range anxieties or extra efforts for fuel procurement activities. Spreading sales bans for ICE cars as of 2035/2040, which are already planned in several countries (cf. International Energy Agency 2019), across Europe would accelerate the decarbonization. Concerning low-emission trucks, decisions on the deployment of hydrogen refueling stations for FCEV versus catenary system infrastructure for trolley trucks must be taken 
after further experimentation and evaluation within pilot studies. This choice will have a noticeable impact on the provided flexibility potential. Moreover, the overall demand for electricity and hydrogen as well as the provided flexibility potential will depend a lot on the transition type for decarbonizing the transport sector. The High-RES scenario represents a mainly powertrain technology-driven decarbonization pathway. In case of more extensive lifestyle and behavior changes, e.g., with decreasing car-ownership rates, more use of multi-modal transport, micro-mobility, biking and walking, and large fleets with shared and autonomous cars, impacts on the electricity system might be quite different both in terms of absolute electricity demand and load shifting potentials due to changing load profiles and requirements.

In the iron and steel, cement and chemicals industries, deep emission cuts require substantial changes but also support for RES and energy efficiency in other sectors and companies (excluding the use of CCS in industry). In the long-term, RES-based use of electricity - either directly or indirectly via secondary energy carriers like hydrogen - can play a more important role, if electricity generation can be provided $\mathrm{CO}_{2}$-free. However, in order to have new process technologies and innovations ready by 2030 , substantial research, development, and innovation activities need to take place in the coming decade. Consequently, the current policy mix needs to be adjusted in order to effectively support R\&D activities directed at the decarbonization of industrial production (e.g., ETS-minimum price path, public R\&D funding). In general, it is necessary to set incentives toward a low-carbon industry as early as possible to accelerate the market entry of efficient and innovative processes as increases of $\mathrm{CO}_{2}$ price probably take place after 2040 and consequently affect only a small share of investment decisions taken.

The described technology diffusion in this study leads not only to a higher demand for electricity but also to large flexibility potentials on the demand side. The new potentials exceed the "classical" flexibility options, such as heat pumps and refrigeration, in terms of the shiftable amount of load. However, the number and thus the local distribution of new flexibility options is limited, e.g., the hydrogen electrolysis. Due to their broad diffusion, classic flexibility options could still be a relevant option in low voltage grids to support grid stability. This analysis, though, did not focus on the effect of flexibility deployment in distribution grids.

In order to make use of the future demand side flexibility potential, it is necessary to incentivize flexibility deployment for system stability and renewable integration. A possibility would be the introduction of time-variable electricity prices or to enable the participation of demand side actors in balancing power and flexibility markets.

To conclude, demand side management of the disruptive technologies can contribute to the flexibility needs of RES integration, but requires appropriate regulations. As quite distinct developments of the sector transitions are possible, demand side flexibility contributions should be further investigated for different decarbonization pathways. 


\section{References}

Barbour E, González MC (2018) Projecting battery adoption in the prosumer era. Appl Energy 215:356-370. https://doi.org/10.1016/j.apenergy.2018.01.056

Boßmann T (2015) The contribution of electricity consumers to peak shaving and the integration of renewable energy sources by means of demand response: a model-based long-term scenario analysis in consideration of structural changes in electricity demand. Fraunhofer Verlag, Stuttgart, Germany

Buttler A, Spliethoff H (2018) Current status of water electrolysis for energy storage, grid balancing and sector coupling via power-to-gas and power-to-liquids: a review. Renew Sustain Energy Rev 82:2440-2454. https://doi.org/10.1016/j.rser.2017.09.003

Chan Y, Petithuguenin L, Fleiter T, Herbst A, Arens M, Stevenson P (2019) Industrial innovation: pathways to deep decarbonisation of Industry: part 1: technology analysis. ICF and Fraunhofer ISI

Dechema (2017) Low carbon energy and feedstock for the European chemical industry: technology Study. Study commissioned by CEFIC, Frankfurt, Germany. https://dechema.de/2017+7+Cefic_ Studie-p-20073830.html (Accessed July 2020)

De Vita A, Kielichowska I, Mandatowa P, Capros P, Dimopoulou E, Evangelopoulou S, Fotiou T, Kannavou M, Siskos P, Zazias G, De Vos L, Dadkhah A, Dekelver G (2018) Technology pathways in decarbonisation scenarios. https://ec.europa.eu/energy/sites/ener/files/documents/ 2018_06_27_technology_pathways_-_finalreportmain2.pdf (Accessed July 2020)

Eichhammer W, Herbst A, Pfaff M, Fleiter T, Pfluger B (2018) Impact on the environment and the economy of technological innovations for the Innovation Fund (IF): in the fields of: energyintensive industries, renewables, carbon capture and storage/use (CCS/CCU), energy storage. Publications Office of the European Union, Luxembourg

European Commission (2018) A Clean Planet for all: a European long-term strategic vision for a prosperous, modern, competitive and climate neutral economy. In-depth analysis in support of the Commission communication $\operatorname{COM}(2018) 773$, Brussels

Figgener J, Haberschusz D, Kairies KP, Wessels O, Tepe B, Ebbert M, Herzog R, Sauer DU (2017) Wissenschaftliches Mess- und Evaluierungsprogramm Solarstromspeicher 2.0: Jahresbericht 2017. Aachen, Germany.

Fleiter T, Herbst A, Rehfeldt M, Arens M (2019) Industrial innovation: pathways to deep decarbonisation of Industry. Part 2: Scenario analysis and pathways to deep decarbonisation. ICF and Fraunhofer ISI

Gnann T, Klingler AL, Kühnbach M (2018) The load shift potential of plug-in electric vehicles with different amounts of charging infrastructure. J Power Sources 390:20-29. https://doi.org/ 10.1016/j.jpowsour.2018.04.029

Gutiérrez-Martín F, Ochoa-Mendoza A, Rodríguez-Antón LM (2015) Pre-investigation of water electrolysis for flexible energy storage at large scales: the case of the Spanish power system. Int J Hydrogen Energy 40:5544-5551. https://doi.org/10.1016/j.ijhydene.2015.01.184

Herbst A, Fleiter T, Rehfeldt M, Lux B, Pfluger B, Sensfuß F, Bernath C, Maranon-Ledesma H, Scherwath T, Holz F (2018) D.5.5: Summary report on case study: the contribution of innovative technologies to decarbonise industrial process heat. A report compiled within the H2020 project SET-Nav. Wien: Technische Universität Wien

Heitel S, Seddig K, Gómez Vilchez JJ, Jochem P (2019) Global electric car market deployment considering endogenous battery price development. In: Junginger M, Louwen A (eds) Technological learning in the transition to a low-carbon energy system. Elsevier, London

International Energy Agency (2019) Global EV Outlook 2019: Scaling-up the transition to electric mobility. https://webstore.iea.org/global-ev-outlook-2019. (Accessed July 2020)

Klingler AL, Schreiber S, Louwen A (2019) Stationary batteries in the EU countries, Norway and Switzerland: Market shares and system benefits in a decentralized world. 16th International Conference on the European Energy Market (EEM), Ljubljana 
Krail M (2009) System-based analysis of income distribution impacts on mobility behaviour. Karlsruher Beiträge zur wirtschaftspolitischen Forschung, vol 28. Nomos Verlagsgesellschaft, Baden-Baden.

Louwen A, Krishnan S, Derks M, Junginger M (2018) D3.2 comprehensive report on experience curves. REFLEX project report.

Plötz P, Gnann T, Wietschel M, Kluschke P, Doll C, Hacker F, Blanck R, Kühnel S, Jöhrens J, Helms H, Lambrecht U, Dünnebeil F (2018) Alternative drive trains and fuels in road freight transport-recommendations for action in Germany. Karlsruhe, Berlin, and Heidelberg. https:// publica.fraunhofer.de/dokumente/N-521306.html (Accessed July 2020)

Rogers EM (2003) Diffusion of innovations, 5th edn. Free Press, New York, London, Toronto, and Sydney

Scherrer A, Burghard U, Wietschel M, Dütschke E (2019) Early Adopter von EFahrzeugen: Ladeleistungen, Eigenerzeugung und Einstellungen zum Lademanagement. Energiewirtschaftliche Tagesfragen 69(11):23-26

Schill WP, Zerrahn A, Kunz F (2017) Prosumage of solar electricity: pros, cons, and the system perspective. Econ Energy \& Environ Policy 6:7-31. https://doi.org/10.5547/2160-5890.6.1.wsch

Schmidt O, Hawkes A, Gambhir A, Staffell I (2017) The future cost of electrical energy storage based on experience rates. Nat Energy 2:964. https://doi.org/10.1038/nenergy.2017.110

Siderwin (2018) Development of new methodologies for Industrial $\mathrm{CO}_{2}$-free steel production by electrowinning. $\Sigma$ IDERWIN is a European project under the Horizon 2020 framework and the SPIRE initiative. https://www.siderwin-spire.eu (Accessed July 2020)

Slednev V, Bertsch V, Ruppert M, Fichtner W (2018) Highly resolved optimal renewable allocation planning in power systems under consideration of dynamic grid topology. Comput. Oper. Res. https://doi.org/10.1016/j.cor.2017.12.008

Stahl B, Klingler AL, Klobasa M, Manz P, Pudlik M (2018) Integration of small-scale batteries into future electricity markets. 15th International Conference on the European Energy Market (EEM), Lodz, Poland, 27-29 June 2018

Sterner M, Eckert F, Thema M, Bauer F (2015) Der positive Beitrag dezentraler Batteriespeicher für eine stabile Stromversorgung: Kurzstudie im Auftrag des BEE e.V. und der Hannover Messe. Regensburg, Berlin, and Hannover. https://www.bee-ev.de/fileadmin/Publikati onen/BEE_HM_FENES_Kurzstudie_Der_positive_Beitrag_von_Batteriespeichern_2015.pdf. (Accessed July 2020)

Vogl V, Åhman M, Nilsson LJ (2018) Assessment of hydrogen direct reduction for fossil-free steelmaking. J Clean Prod 203:736-745. https://doi.org/10.1016/j.jclepro.2018.08.279

Wietschel M, Gnann T, Kühn A, Plötz P, Moll C, Speth D, Buch J, Boßmann T, Stütz S, Schellert M, Rüdiger D, Schade W (2017) Machbarkeitsstudie zur Ermittlung der Potentiale des HybridOberleitungs-Lkw. Study on behalf of the German Federal Ministry of Transport and Digital Infrastructure, Karlsruhe

Zöphel C, Schreiber S, Herbst A, Klingler AL, Manz P, Heitel S, Fermi F, Wyrwa A, Raczyński M, Reiter U, Möst D (2019) Report on cost optimal energy technology portfolios for system flexibility in the sectors heat, electricity and mobility, REFLEX project report 
Open Access This chapter is licensed under the terms of the Creative Commons Attribution 4.0 International License (http://creativecommons.org/licenses/by/4.0/), which permits use, sharing, adaptation, distribution and reproduction in any medium or format, as long as you give appropriate credit to the original author(s) and the source, provide a link to the Creative Commons license and indicate if changes were made.

The images or other third party material in this chapter are included in the chapter's Creative Commons license, unless indicated otherwise in a credit line to the material. If material is not included in the chapter's Creative Commons license and your intended use is not permitted by statutory regulation or exceeds the permitted use, you will need to obtain permission directly from the copyright holder.

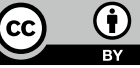

